\title{
A Preliminary Study of Novel Coronavirus Disease (COVID-19) Outbreak: A Pandemic Leading Crisis in Tourism Industry of Nepal
}

\author{
Nimesh Ulak \\ Lecturer, IST College, Kathmandu \\ nimeshulak@gmail.com
}

Article History

Received 6 April 2020

Accepted 20 April 2020

Keywords

COVID-19,

pandemic, tourism

crisis, impacts, crisis

management
Corresponding Editor

Ramesh Raj Kunwar

kunwar.dr@gmail.com

\section{Abstract}

The aim of this paper is to explore and illuminate the preliminary impacts of novel coronavirus disease (COVID19) in tourism industry of Nepal. The spillover impact of pandemic has been seen in almost every sector globally. Many scholars and practitioners have already started rethinking and researching in different disciplines based on issues regarding COVID-19. Some of the disciplines are International tourism, health sector, international economy, global politics, human civilization, sustainability and so on. The United Nation World Tourism Organization (UNWTO) and World Health Organization (WHO) are closely cooperatingfor understanding the severe impact of escalation of coronavirus on the human health and damage in the world economy as well as tourism sector (UNWTO, 2020). There are uncountable job losses recorded in tourism industry due to stranded traveler's mobility after many nations including Nepal declared lockdown as a strategy to control the spread of virus Therefore, devastating Airlines, shuttered borders, halt of transportation means and cancellation of rooms in hotels have a vigorous impact on tourism industry than the COVID-19 outbreak itself. It is 
obvious to experience changes in tourism industry; tourist's behavior and their reluctance to travel for few years. However, travel of humans for any motives will provides spectrum to tourism mobility. The epidemic has drastically turned into pandemic as the virus has transferred to almost all the nations of the globe without visa so far.

\section{Introduction}

Tourism industry christened as a "fickle" industry, "seasonal" industry, "peace" industry, one of the "largest" industries and so on (Kunwar, 2010, p.12). Tourism plays an important role in enhancing a nation's business activity, income, foreign currency earnings and the creation of jobs. Thus, the tourism industry tends to be highly sensitive to negative environmental factors such as natural disasters, epidemics, serious social conflicts, war, economic crises and terrorism acts (Hung, et al., 2007). As a result, these kinds of events influences tourism mobility and traveler's motivation to travel which will have lasting effects on tourism industry. The outbreak of coronavirus also has developed a fear on travelers.

Tourism industry of Nepal has been facing many crisis and obstacles since its inception. Nepal has been officially open for international tourist since 1951 (MoCTCA, 2014). There have been crises and disasters which have directly affected tourism industry of Nepal in different time period (see table.1). The sector was hardhit by earthquake, trade blockade in the year 2015, now it is COVID-19 pandemic. 2020)

Table 1: Negative Events and its Impacts in Tourism Industry of Nepal (2015-

\begin{tabular}{|l|l|l|}
\hline Negative Events & Year & Tourism Decline (\%) \\
\cline { 1 - 2 } Catastrophic Earthquake & 2015 & \multirow{2}{*}{$33 \%$} \\
\cline { 1 - 2 } Trade Disruptions along the southern border & 2015 & \\
\cline { 1 - 2 } COVID-19 Pandemics & $2019-2020$ & N/A \\
\hline
\end{tabular}

Source: Economic Impact, Asian Development Bank (2019)

\section{What is coronavirus?}

Coronaviruses have been described for more than 50 years; as the name "coronavirus', was coined in the year 1968 (Weiss \& Martin, 2005, p. 636).Weiss and Martin (2005) also highlights interesting fact about the coronavirus, that "the name "Corona" comes from Italian and Spanish term which means crown as the structure of virus seems to be similar "corona"-like or crown-like when observed through electron microscope". On February 11, 2020, the International Committee on Taxonomy of Viruses, charged with naming new virus, named the novel coronavirus (2019- nCoV). In the $21^{\text {st }}$ century, there are two identified immense drivers of change to tourism industry are climate change and global health emergencies (Jamal \& Budke, 2020). 


\section{Purpose and method of study}

The main purpose of this study is to analyze the preliminary impact of COVID19 outbreak as a pandemic affecting traveler's mobility and its impact on tourism industry of Nepal. The questions are what are the impacts of COVID-19 in tourism industry of Nepal? How will a developing country like Nepal handle the post pandemic tourism crisis?

The study is exploratory in nature that follows qualitative method of analysis. The study has been carried out until April 11, 2020 only. Hence, updates after April 11 , has not covered in this study. The study is based on secondary data through desk research. The data are extracted from published journals, articles and emerging media coverage sources. Basically, the data are drawn on the theme of impacts of crisis in tourism industry from published papers and media publications based on multi-disciplinary approach in regards to the crisis management, impacts of crisis on tourism industry.

\section{Literature review}

According to Hock et al. (2004), "three human coronaviruses are known to exist: human coronavirus 229E (HCoV-229E), HCoV-OC43 and severe acute respiratory syndrome (SARS)-associated coronavirus (SARS-CoV)". COVID-19 outbreak is not the first case of coronavirus disease as several coronaviruses have caused serious problems in humans and animals in the past decades. The best known examples are Severe Acute Respiratory Syndrome Coronavirus (SARS-CoV), Middle East Respiratory Syndrome coronavirus (MERS-CoV) and Porcine Epidemic Diarrhea virus (PEDV). These viruses are known to have high mutation and recombination rates, which may allow them to cross species barriers and adapt to new host. Hence, the emergence and re-emergence of some of these viruses are pathogens to humans and animals (Lau \& Chan, 2015).

Hu et al. (2020) have attempted to connect the effects of naming the virus and its repercussion in society. Their study claims that, before gauging COVID-19 epidemic and COVID-19 infodemic, it is necessary to take a glimpse into the history of scientific taxonomy and nomenclature of emerging virus and infectious disease. However, as an earlier nomenclature practice, the naming history of coronaviruses $(\mathrm{CoV})$ is always misjudged in scientific community. As a case in point, some strongly-held but flawed names such as "Middle Eastern Respiratory Syndrome" and "Swine flu" were accused of unintentional social impacts and negative economic by stigmatizing certain industries or communities "Swine flu," an influenza strain known to have originated in pigs, resulted in causing great financial damage to farmers, despite there being no evidence that it could be spread via pork consumption. Since these incidents, in May 2015, WHO has released some naming conventions for naming of the new human 
diseases. Unfortunately, with the spread of COVID-19 epidemic, another massive infodemic spread virally over the world with recurring episodes.

Corona beer is being slashed by the name's similarity to the deadly coronavirus. In fact, the Mexican brand originated back in 1925 before the first strain of coronavirus was discovered and named, and nothing to do with coronavirus or virus. To address such challenge, WHO declared this infodemic as the "2019-nCoV (COVID-19) infodemic" on 2 February (Hu et al., 2020). Recently, the COVID-19 infection is not limited to human transmission but has also started infecting economic system and socio-cultural establishments. There has been an interesting and unfortunate instance of coronavirus impact on the famous beer- "Corona Beer" a product of Mexican. Eater.Com published news on this topic that "There is no Link between COVID -19 and Corona beer". Zhang (2020) writes that, it is recorded to have reduced sales and consumption in the month of February, 2020 by more than $20 \%$ which is US $\$ 40$ million that costs the company just because their brand name is Corona. Similarly, there are many brands in the globe named-Corona which is suffering just because of the name. Likewise, the virus outbreak has also results in racism attacks in many parts of the world-"Asian Community" are targeted and vandalized reports has been common which would result in the worst case scenario of damaged socio-cultural system. Haynes (2020) published a report on Time.com in March 11, 2020 entitled "As Coronavirus Spreads, So Does Xenophobia and Anti-Asian Racism". The report publishes that, Singaporean student and a Vietnamese art curator are reported to be the latest targets of xenophobia and racism related to coronavirus in the U.K., as a growing number of incidents have been reported around the world since the outbreak started (Haynes, 2020).

Guo et al. (2020) tries to clarify the clinical characteristics of COVID-19 that, as an emerging acute respiratory infectious disease, COVID-19 primarily spreads through the respiratory tract, by droplets, respiratory secretions, and direct contact for a low infective dose. COVID-19 is contagious during the latency period. It is highly transmissible in humans, especially in the elderly and people with underlying diseases. The median age of patients is $47-59$ years, and $41.9-45.7 \%$ of patients were females. As it is designated SARS-CoV-2, COVID-19 patients presented certainly similar symptoms, such as fever, malaise, and cough. Most adults and children with SARS-CoV-2, COVID-19 infection presented with mild flu like symptoms and a few patients are in critical conditions and rapidly develop acute respiratory syndrome, respiratory failure, multiple organ failure and even death.

Lau \& Chan (2015) presents a data regarding the mortality rate caused by the pandemics like SARS and MERS that MERS has an higher mortality rate $(>35 \%)$ than SARS (9.6\%). Likewise, comparative data of Asian Development Bank (ADB) Briefs (2020) in table. 2 shows that the fatality rate of COVID-19 as compared to other 
epidemics is lower; however, the infection rate is comparatively higher which has created a new fear to travelers.

Table.2: Fatality Rates and Infection Rates of COVID-19 and Other Epidemics

\begin{tabular}{|l|l|l|}
\hline \multicolumn{1}{|c|}{ Epedemics } & $\begin{array}{c}\text { Fatality Rate } \\
\text { (Deaths/ } \\
\text { Cases) }\end{array}$ & \multicolumn{1}{|c|}{$\begin{array}{c}\text { Infection Rate } \\
\text { (per infected } \\
\text { persons) }\end{array}$} \\
\hline Ebola & $50 \%$ & $1.5-2.5$ \\
\hline Middle East Respiratory Syndrome (MERS) & $34.30 \%$ & $0.42-0.92$ \\
\hline Severe Acute Respiratory Syndrome (SARS) & $10 \%$ & 3 \\
\hline COVID-19 & $1 \%-3.4 \%$ & $1.5-3.5$ \\
\hline Seasonal Flu & $0.05 \%$ & 1.3 \\
\hline
\end{tabular}

Source: ADB Briefs No. 128 (2020)

\section{Pandemics}

Moren (2009) elaborated the term pandemic for better understanding, since there was no single accepted definitions where the author argues that the diseases are commonly said to be pandemic only after examining similarities and differences among them. Diseases that we might consider-chosen empirically reflect a spectrum of etiologies, mechanisms of spread, and eras of emergence-include acute hemorrhagic conjunctivitis (AHC), AIDS, cholera, dengue, influenza, plague, severe acute respiratory syndrome (SARS), scabies, West Nile disease, and obesity. The infectious diseases that are considered to be pandemic by public health officials are contagious from person to person, such as influenza. Other diseases have multiple means of transmission, including those that are occasionally contagious but more commonly transmitted by different mechanisms, such as plague (by fleas) and cholera (by water).

Rubin (2011) classified pandemics as a "Global Shock is consistent with considering certain aspects of public health and infectious diseases as "existential threats" to human security" as described in United Nations Development Program (UNDP). The UNWTO (2020) has highlighted that, "COVID-19 is a respiratory illness that was discovered in December, 2019 for the first time in Wuhan, China which has not been previously identified in humans that can spread from person to person. The virus that causes COVID-19 probably emerged from an animal source is a novel coronavirus is basically a respiratory illness". UNWTO is closely monitoring developments related to the outbreak of 2019-nCoV, and its impacts in tourism sector since its outbreak both in China and worldwide. UNWTO is 
also cooperating closely with the WHO. Since the very start of the emergency; the Chinese authorities have acted swiftly and decisively. There are different countries/ territories/ areas having differences in degrees of transmissions as indicated by the differing numbers of cases and other factors. Hence, it has not affected all locations within a given country/territory/area equally (WHO, 2020).

The situation is beyond control since the spread of coronavirus is rapid and has infected COVID-19 to humans of almost all the nation of globe, this situation is commonly known as pandemic. Pandemics are the state of disease that sharply increases in populations around the world with infections taking place more or less simultaneously. The sudden emergence and rapid global spread of a novel H1N1 influenza virus in early 2009 has caused confusion about the meaning of "pandemic" and how to recognize pandemics when they occur (Moren, 2009). Contemporary pandemics and outbreaks of disease, such as the current H1N1 influenza pandemic, as well as the emergence of $\mathrm{H} 1 \mathrm{~N} 1$ influenza virus and the SARS associated coronavirus, severe as poignant reminders of our global vulnerability to emergent threats to human health and our current inability to predict or prevent such events. However, despite the seemingly unpredictable nature of disease emergence there are lessons to be learned from the origins of recently emerged disease as identify practical solutions and strategies aimed at detecting and halting future threats (Pike, et al., 2010, p.1).

\section{Tourism crisis}

The pause of tourism activities and halt of travelers' mobility due to outbreak of COVID-19 has invited crisis in the industry. Tourism crisis is not a new phenomenon, there have been crises in history, such as war and terrorism, which interrupted the growth of tourism, but the study of crisis management in tourism began recently (Tse, 2006,). According to Rocca (2015), tourism is a social, cultural and economic phenomenon, which represents the set of movements generated by the search for places and activities that are different from usual and have no economic motivation which underlines the "mobility" as essential to tourism. Tourism is traditionally associated with leisure and vacation, where tourists look for rejuvenation and relaxation in a holiday, however, crisis affects the tourism mobility.

Sönmez et al. (1994, p.30) had defined tourism crisis as:

"[...] any occurrence which can threaten the normal operations and conduct of tourism related businesses; damage a tourist destination's overall reputation for safety, attractiveness, and comfort by negatively affecting the visitor's perceptions of that destination; and in turn, cause downturn in the local travel and tourism economy, and interrupt the continuity of business operations for the local travel and tourism industry, by the reduction in tourist arrivals and expenditures". 
The similar definition of tourism crisis forwarded by Luhrman (2003), that tourism crisis is:

"[...] any unexpected event that affects traveler confidence in a destination and interferes with the ability to continue operating normally".

Tourism Crisis as a theory developed by Beirman (2011), defines crisis as,

"[...] an event or set of circumstances which can severely compromise or damage the marketability and reputation of a tourism business or an entire tourism development region."

According to Henderson (2007; in Kunwar, 2016, p.16), tourism crises can affect the development of economic, political, socio-cultural and environmental domains that can further affect demand and supply in tourism generating and destination countries The strategic plan of crisis management can possibly reduce the impacts; therefore, evaluation of the effectiveness of these strategic plans can ensure constant refinement of crisis.

Definitions and theories related to crisis in tourism justify the current crisis of pandemic. The fear of COVID-19 has dramatically changed the confidence, perception and motivation which not only has reduced the tourism activities in the destinations but has stopped the mobility of the travelers impacting the global economy into high risk. Many leaders and economists have declared the situation very worst and have started comparing the crisis similar as on the time of world war. The US Department of State issued an advisory against to China on January 30, 2020 and soon after a travel ban was announced preventing entry to any foreign national arriving from China (Maxouris, 2020). Hung et al. (2018) has previously stated on his paper that "based on previous experiences, some hospitality-related stakeholders may be better prepared, in terms of emergency preparation and working with customers".

Mair et al. (2016) argues that, "various tourism researchers have called for proactive crisis response and management planning based on learning from SARS"; however, Jamal \& Budke (2020), did not found the proactive crisis response on this event and depict his view that "Unfortunately, coordinated crisis management and communication plans have rarely been implemented effectively at the local or country level. The issues are not merely economic recovery, destination image management, media management and promotion (common industry-related themes)." It has been always a problem of humans that they do not learn a lesson from its past crisis event or they are least bothered after eradication of crises. 
External and internal threats of crisis

\begin{tabular}{|c|c|c|}
\hline Domain & External & Internal \\
\hline Economic & $\begin{array}{l}\text { Recession, Currency fluctuations, } \\
\text { Taxation }\end{array}$ & $\begin{array}{l}\text { Rising costs, Falling } \\
\text { revenues, Unprofitability }\end{array}$ \\
\hline Political & $\begin{array}{l}\text { Government policy, International } \\
\text { Relations, Instability, Terrorism }\end{array}$ & \\
\hline Socio-cultural & Unrest, Crime & \\
\hline Environmental & $\begin{array}{l}\text { Natural phenomena, Natural } \\
\text { Disaster, Pollution, Health Scares }\end{array}$ & $\begin{array}{l}\text { Staffing, Cultural } \\
\text { conflicts, } \\
\text { Overdevelopment, } \\
\text { Environmental } \\
\text { degradation } \\
\end{array}$ \\
\hline Technological & $\begin{array}{l}\text { Computer system failure, } \\
\text { Mechanical failure, Design faults, } \\
\text { Failure }\end{array}$ & Transportation accidents \\
\hline Commercial & $\begin{array}{l}\text { Regulations, Government } \\
\text { Intervention, Management } \\
\text { decision }\end{array}$ & $\begin{array}{l}\text { Competition, Labor } \\
\text { Disputes }\end{array}$ \\
\hline Human Errors & & \\
\hline
\end{tabular}

Source: Kunwar (2016, p. 16)

\section{Tourism and crisis management}

Barton (1994) was the first person to argue for using crisis management plan as a management tool in the hospitality industry (Kunwar, 2012); however, the concept has been recognized since the 1962 Cuban missile crisis (Kunwar, 2016, p. 28). Tourism crises management process should require contingency plan for each organization and the plan would help the management think and prepare before a risk becomes crisis. Crisis Management is a very common topic in the field of tourism; however, crisis due to COVID-19 pandemic is a new phenomenon for tourism industry. Occurrence of unenviable crisis might takes place for which organization/ industry/ networks/ government are not prepared prior, plans are sometimes only developed in a response to a particular event with varying degrees of speed and efforts. Crisis Management is a critical organizational function (Coombs, 2007). Crisis should be handled properly, effectively and sensitively to reduce impacts and threats sequentially (Ulak, 2016, p.82).

Volumes have been published by both the practitioner and researchers from many disciplines making it challenge to synthesize what we know about Crisis Management 
in that knowledge base (Coombs, 2007). Similarly, many theories were published on crisis and its management as per tourism perspectives; strategies and ideas had been developed and successfully tested to minimize the impacts of crisis. It is Kunwar (2010), who has suggested some essential activities that the destinations should exercise damage control at the time of the negative event. And Kotler et al. (1998; in Kunwar, 2010, p.317) recommended four critical elements for crisis management in this context.

\section{Suggestions and recommendations on managing tourism crisis}

\begin{tabular}{|c|c|}
\hline Kunwar's Suggestions & Kotler et al. recommendation \\
\hline $\begin{array}{l}\text { - Monitoring and managing media } \\
\text { coverage ensuring that all reports } \\
\text { present a balance and accurate picture; }\end{array}$ & $\begin{array}{l}\text { - Appoint a spokesperson to handle } \\
\text { the media; }\end{array}$ \\
\hline $\begin{array}{l}\text { - Conducting background briefings for } \\
\text { journalists, tour operators, and travel } \\
\text { agents; }\end{array}$ & $\begin{array}{l}\text { - The spokesperson should gather } \\
\text { the facts and stick them in } \\
\text { reporting }\end{array}$ \\
\hline $\begin{array}{l}\text { - Limiting harm to tourists already on the } \\
\text { location; }\end{array}$ & - Contact PR agency immediately; \\
\hline $\begin{array}{l}\text { - Restricting damage to tourism } \\
\text { infrastructure and showing tourism } \\
\text { services operating normally; }\end{array}$ & $\begin{array}{l}\text { - Notify the press and keep them } \\
\text { informed. }\end{array}$ \\
\hline $\begin{array}{l}\text { - Seeking assurances from source } \\
\text { governments that they will support a } \\
\text { destination's attempts to control the } \\
\text { problems. }\end{array}$ & \\
\hline
\end{tabular}

Source: Kunwar (2010, p. 317)

With the WHO declaring the public health emergency of global concern; Gloria Guevara- President and CEO of the World Travel and Tourism Council (WTTC) fears that this escalation could have damaging and lasting economic impact on the tourism sector (UNWTO, 2020). Tourism industry is no exception; therefore, tourism mobility has drastically reduced or temporarily halted. To overcome this worst situation, WHO came up with major preparedness and response required to tackle the COVID-19 pandemic. 


\section{Major preparedness and response of World Health Organization (WHO)}

Who has been periodically updating the Global Surveillance for Human Infection with Covid-19 document which includes case definitions. https://www.who. int/publications-detail/global-survellience-for-human-infection-with-novelcoronavirus-(2019-ncov).

WHO has developed interim guidance for laboratory diagnosis, advice on the use of masks during human care and in health care settings in the context of the 2019-nCoV outbreak, clinical management, infection prevention and control in health care settings, home care for patients with suspected novel corona virus, risk communication and community engagement and global surveillance for human infection with 2019-nCoV.

WHO is working closely with International Air Transport Association (IATA) and have jointly developed a guidance document to provide advice to cabin crew and airport workers, based on country queries. The guidance can be found in IATA webpage (www.iata.org/en/programs/safety/health/diseases/\#tab-2)

WHO has been in regular and direct contact with Member States where cases has been reported. WHO is also informing other countries about the situation and providing support as requested.

WHO is working with its networks of researchers and other experts to coordinate global work on surveillance, epidemiology, mathematical modeling, diagnostics and virology, clinical care and treatment, infection prevention and control, and risk communication. WHO has issued interim guidance for countries, which are updated regularly.

Source: Coronavirus disease 2019 (COVID_19) Situation Report, WHO (2020)

WHO has developed some terms related to COVID-19 pandemic as a strategy to group the medium of infection, on the base of these terms the case of transmissions are minutely observed for breaking its routes. The terms are:

Terms on COVID-19 developed by World Health Organization

\begin{tabular}{|l|l|}
\hline Terms & Meaning \\
\hline $\begin{array}{l}\text { Community } \\
\text { transmission }\end{array}$ & $\begin{array}{l}\text { is evidenced by the inability to relate confirmed cases through } \\
\text { chains of transmission for a large number of cases, or by } \\
\text { increasing positive tests through sentinel samples (routine } \\
\text { systematic testing of respiratory samples from established } \\
\text { laboratories). }\end{array}$ \\
\hline $\begin{array}{l}\text { Local } \\
\text { transmission }\end{array}$ & $\begin{array}{l}\text { indicate locations where the source of infection is within the } \\
\text { reporting location. }\end{array}$ \\
\hline
\end{tabular}




\begin{tabular}{|l|l|}
\hline Terms & Meaning \\
\hline $\begin{array}{l}\text { Imported cases } \\
\text { only }\end{array}$ & $\begin{array}{l}\text { indicate locations where all cases have been acquired outside the } \\
\text { location of reporting. }\end{array}$ \\
\hline $\begin{array}{l}\text { Under } \\
\text { investigation }\end{array}$ & $\begin{array}{l}\text { indicates locations where the type of transmission has not been } \\
\text { determined of any cases. }\end{array}$ \\
\hline $\begin{array}{l}\text { Interrupted } \\
\text { transmission }\end{array}$ & $\begin{array}{l}\text { indicates locations where interruption of transmission has been } \\
\text { demonstrated (details to be determined). }\end{array}$ \\
\hline
\end{tabular}

Source: WHO Situation Update (2020)

Over the past few months, the world has been hit by a large scale viral outbreakcoronavirus- that causes COVID-19. As of April 10, 2020, surveillance data of WHO published on COVID-19 Situation Report-81 shows the total number of confirmed cases of coronavirus infection worldwide surpassed 1521252 and the death count reached 92798 (WHO, 2020).

The infection case rates and death counts are changing in no time. Nepal has already reported nine cases out of which first case was confirmed in Kathmandu on January 24, 2020 who was subsequently confirmed to have completely recovered. Nepal seems be proactive and effective in maintaining the low rate of case till date by implementing a country-wide lockdown which came into effect on $24 \mathrm{March}$, and is scheduled to end on 15 April; closure of international airport and borders shutdown in the south and north; and isolating the citizens who have traveled in international destinations and quarantining the suspect. The Economic Times (2020) published a report that, there are four stages of pandemics and they entail:

\section{Four stages of pandemics}

\begin{tabular}{|l|l|}
\hline Stage 1 & $\begin{array}{l}\text { In the first stage of pandemic, the disease does not spread locally-cases } \\
\text { reported are usually people who have had travel history to an already } \\
\text { affected country }\end{array}$ \\
\hline Stage 2 & $\begin{array}{l}\text { This is the stage of local transmission-when people who have brought } \\
\text { the virus into the country transmit it to the people they come in contact } \\
\text { with, usually friends and family. At this stage, it is easy to trace spread and } \\
\text { quarantine people. }\end{array}$ \\
\hline Stage 3 & $\begin{array}{l}\text { The third stage is when the source of the infection is untraceable; this } \\
\text { stage is identified by people who haven't had travel history getting affected } \\
\text { by the virus - once here spread is extremely contagious and difficult to } \\
\text { control. }\end{array}$ \\
\hline
\end{tabular}


\begin{tabular}{|l|l|}
\hline Stage 4 & $\begin{array}{l}\text { So far, China has been the only country to experience Stage } 4 \text {, where } \\
\text { spread is practically uncontrollable and there are many major clusters of } \\
\text { infection all over the country. }\end{array}$ \\
\hline
\end{tabular}

Source: The Economic Times (2020)

Nepal is in a second stage of pandemic as seven of the eight active cases involve people who had recently returned from abroad; the first case of local transmission was confirmed on April 4, 2020 in a 34-year-old woman from Kailali (Neupane, 2020). According to Institute of Public Relations (2007), crisis management is a process designed to prevent or lessen the damage as crisis can inflict the industry. As a process, crisis management is not just a single job; it can be divided into three phases- Pre-Crisis phase, Crisis Response Phase, and Post Crisis Phase.

Coombs (2006; in Institute of Public Relations, 2007) argues that, that the team who is handling the crisis should be able to handle crisis effectively when they- have a crisis management plan that is updated at least annually; have a designated crisis management team; conduct exercises to test the plans and teams at least annually; and pre-draft some crisis messages. Institute of Public Relations (2007) also highlights that, the crisis response is the second phase of crisis management after the crisis hits. There are two sections in this phase (1) initial crisis response and (2) reputation repair and behavioral intensions. The initial crisis response is the preparedness to the crisis to reduce the impacts. Therefore, Ministry of Health and Population (MoHP) and Department of Health Services (DoHS,) came up with institutional framework which works as a supporting mechanism for lower levels by providing logistical, financial, supervisory and technical support from the center to periphery for these natures of health crisis. It is very important to communicate during the crisis events; hence, crisis communication channel preparation developed by Institute of Public Relation (2007) could be the best practice to communicate for the tourism industry and other sectors in this situation.

1. Be prepared to use a unique website or part of your current website to address crisis concerns.

2. Be prepared to use the Intranet as one of the channels for reaching employees and any other stakeholders than may have access to your intranet.

3. Be prepared to utilize a mass notification system for reaching employees and other key stakeholders during crisis.

\section{Preparedness and response to COVID_19}

According to The World Bank (2020) press release, “The Government of Nepal and the world Bank sign \$29 million financing agreement for Nepal's COVID-19 (Coronavirus) emergency response and health systems preparedness. This Project 
has helped Nepal to prevent, detect, and respond the COVID-19 pandemic and strengthen its public health preparedness". The project will basically focus on the rapid response and preparedness to fight the virus. The support to Nepal by World Bank is to enhance the capacity and detect cases and ensuring prompt contact tracing consistent with WHO guidelines and MoHP protocols. The project has also helped to setup required intensive care units, beds, and isolation facilities across the country. The World Bank project will also equip designated health facilities with personal protective equipments (PPE) and hygienic materials along with capacity enhancement of laboratories to respond public health emergencies and strengthen the health institutions (The World Bank, 2020).

As per MoHP (2020), the preparedness and response of Nepal for coping with COVID-19 pandemic are:

- Nepal established health-desks at the international airport and border check points starting in mid-January with India.

- Nepal government called lock down effective from 24 March, 2020 to 15 April, 2020. The lock down also sealed the land-borders with India and China along with all international flights suspended.

- Schools/Colleges and other educational institutions were closed. Academic examinations were cancelled.

- Temporary hospitals and quarantine centers are being set up across the country.

- Laboratory facilities are being upgraded and expanding.

- Hospitals are expanding ICU units and isolation beds are adding

- Required medicines and test-kits are arranging

\section{Impact of COVID-19 in tourism industry of Nepal}

Tourism Industry of Nepal was gradually shifting from passive-impetus to activeimpetus. The hope of growth in the industry was high as there are many hotels and restaurants projects under-constructions have been halted. However, Megaprojects like Gautam Buddha International Airport in Lumbini, Pokhara Regional International Airport, Tribhuvan International Airport Capacity building, Fast-track road to Nijgadh, are under construction phase to cater the tourism industry of Nepal. Government of Nepal has to cancel the very ambitious "Visit Nepal 2020" Campaign temporarily which was inaugurated on January '2020 as a national event targeting 2 million tourists by 2020, almost 100\% increase compared to 2018 .

According to Asian Development Bank (ADB) Report (2019), tourism industry has a distinctive place in Nepal's economy and the industry earns on an average 
$25 \%$ of the total foreign exchange and provides direct employment to more than 200,000 people. The average direct tourism contribution to national economy has hovered at 3.9\% in the GDP from 2008-2018" (ADB, 2019). Nepal's economy has started suffering as a pinch from the initial phase of outbreak of the virus. Nepal's tourism-based economy is being severely impacted due to travel restrictions imposed by Nepal and other countries, and airlines cancelling flights (Subba, 2020). China is the second highest source of tourist in Nepal; and Chinese have stopped traveling as China Government restricted travelling who contributed $20 \%$ to the hotel occupancy, have dwindled and travelers from other countries have also cut short their plan since the wake of outbreak. The sector contributes 14.37 percent to the economy, according to Central Bureau of Statistics (Shrestha, 2020).

The contemporary situation of Nepal's tourism industry is significantly affected by COVID-19. Tourism is a seasonal industry (Kunwar, 2010), April -March are the highest tourist season of Nepal but the industry has gone to coma because of COVID-19. The significant effect of this situation is yet to come and it requires long time to cure. Prashain (2019) reports that, "more than 1.05 million jobs directly and indirectly related to tourism industry are affected. The national economy is adversely affected as this sector generated NRs. 240.7 billion in revenue in 2018", according to World Travel and Tourism Council Research Report”. Prashian further added "travel and tourism's total contribution to the country's GDP stood at 7.9 percent in the year 2018, up by 3.6 percent”. The Travel and Tourism Economic Impact (2019) report shows that, the tourism industry of Nepal has been gradually expanding as the contribution of tourism industry in GDP was rise by NRs.45.7 billion. The total contribution of tourism industry to GDP in 2017 was NRs. 195 billion. Nepal Rastra Bank Report in Travel and Tourism Economic Impact (2019) shows that, the total foreign currency exchange for 2018 stood at around 617,263 thousand US\$ which was almost $17 \%$ higher than in the year 2017 . The average daily spending of tourist in Nepal is US\$ 44 (MoCTCA, 2019). There will be tourism nostalgia while looking at the comparative growth of tourism industry of Nepal from the year 2012-2017.

Table.3: Tourism Arrival, Length of Stay and Tourism Related Enterprise (2012-2017)

\begin{tabular}{|l|c|c|c|c|c|c|c|}
\hline $\begin{array}{l}\text { Tourist } \\
\text { arrival by }\end{array}$ & $\mathbf{2 0 1 2}$ & $\mathbf{2 0 1 3}$ & $\mathbf{2 0 1 4}$ & $\mathbf{2 0 1 5}$ & $\mathbf{2 0 1 6}$ & $\mathbf{2 0 1 7}$ & $\begin{array}{l}\text { Increase } \\
\text { in 2017 }\end{array}$ \\
\hline Air & 598,258 & 594,848 & 585,981 & 407,412 & 572,563 & 760,577 & $32.8 \%$ \\
\hline Land & 204,834 & 202,768 & 204,137 & 131,558 & 180,439 & 179,641 & $-0.4 \%$ \\
\hline Total & 803,092 & 797,616 & 790,118 & 538,970 & 753,002 & 940,218 & $24.9 \%$ \\
\hline
\end{tabular}




\begin{tabular}{|c|c|c|c|c|c|c|c|}
\hline $\begin{array}{l}\text { Tourist } \\
\text { arrival by }\end{array}$ & 2012 & 2013 & 2014 & 2015 & 2016 & 2017 & $\begin{array}{c}\text { Increase } \\
\text { in } 2017\end{array}$ \\
\hline $\begin{array}{l}\text { Average } \\
\text { length } \\
\text { of stay } \\
\text { (Days) }\end{array}$ & 12.2 & 12.6 & 12.4 & 13.2 & 13.4 & 12.6 & $-6.0 \%$ \\
\hline \multicolumn{8}{|c|}{ Tourism Related Enterprises } \\
\hline $\begin{array}{l}\text { Hotel } \\
\text { (Star) }\end{array}$ & 107 & 117 & 118 & 116 & 120 & 125 & $4.2 \%$ \\
\hline $\begin{array}{l}\text { Hotel } \\
\text { (Non-star) }\end{array}$ & 746 & 909 & 957 & 957 & 924 & 977 & $3.7 \%$ \\
\hline $\begin{array}{l}\text { Beds } \\
\text { (number) }\end{array}$ & 31,657 & 34,523 & 36,179 & 36,950 & 38,242 & 39,833 & $4.2 \%$ \\
\hline $\begin{array}{l}\text { Travel } \\
\text { agencies }\end{array}$ & 2,239 & 2,450 & 2,611 & 2,768 & 3,444 & 3,824 & $11.0 \%$ \\
\hline $\begin{array}{l}\text { Trekking } \\
\text { agencies }\end{array}$ & 1,598 & 1,761 & 1,903 & 2,016 & 2,367 & 2,637 & $11.4 \%$ \\
\hline $\begin{array}{l}\text { Tourist } \\
\text { guide }\end{array}$ & - & 3,141 & 3,335 & 3,507 & 3,717 & 3,876 & $4.3 \%$ \\
\hline $\begin{array}{l}\text { Trekking } \\
\text { guide }\end{array}$ & - & 9,741 & 10,436 & 11,358 & 13,049 & 13,831 & $6.0 \%$ \\
\hline
\end{tabular}

Source: MoCTCA in ADB (2019)

Table 4: The Fact Sheet shows the Differences in 2017 and 2018

\begin{tabular}{|l|l|l|l|}
\hline Indicators & $\mathbf{2 0 1 7}$ & $\mathbf{2 0 1 8}$ & \% Change \\
\hline Tourist Arrival by: & 760577 & 969287 & 27.44 \\
\hline Air & 179641 & 203785 & 13.44 \\
\hline Land & 12.6 & 12.4 & -1.59 \\
\hline Average Length of Stay
\end{tabular}

Source: Nepal Tourism Statistics (2019)

\section{Tourism sub-sectors of Nepal}

The major sub sectors of tourism industry in Nepal as listed in the Department of Tourism are travel agencies, trekking agencies, rafting agencies, tourist transportation service, tour guide and river guide besides these, hotel industry and airlines which are closed and employees are affected as being temporary unemployment. 
Table.5: Tourist Industries and Guide in Nepal

\begin{tabular}{|c|c|c|c|c|c|c|c|}
\hline Year & $\begin{array}{c}\text { Travel } \\
\text { Agency }\end{array}$ & $\begin{array}{c}\text { Trekking } \\
\text { Agency }\end{array}$ & $\begin{array}{c}\text { Rafting } \\
\text { Agency }\end{array}$ & $\begin{array}{c}\text { Tourist } \\
\text { Transportation } \\
\text { service }\end{array}$ & $\begin{array}{c}\text { Tour } \\
\text { Guide }\end{array}$ & $\begin{array}{c}\text { Trekking } \\
\text { Guide }\end{array}$ & $\begin{array}{c}\text { River } \\
\text { Guide }\end{array}$ \\
\hline $2074 / 75$ & 3508 & 2649 & 73 & 77 & 4126 & 16248 & 253 \\
\hline
\end{tabular}

Source: Department of Tourism, MoCTCA (2019)

Table.6: Some Economic Indicators of Hotel and Restaurant

\begin{tabular}{|c|c|c|c|}
\hline Economic Indicators & $\begin{array}{l}2073 / 2074 \\
2015 / 2016 \\
\end{array}$ & $\begin{array}{l}2074 / 2075 \\
2017 / 2018\end{array}$ & $\begin{array}{l}2075 / 2076 \\
2018 / 2019\end{array}$ \\
\hline Annual Growth Rate at constant price (\%) & 7.33 & 9.77 & 8.33 \\
\hline Proportion of Gross Domestic Product (\%) & 1.98 & 2.05 & 2.05 \\
\hline Gross Domestic Product Deflector & 384.53 & 408.68 & 425.63 \\
\hline
\end{tabular}

Source: Nepal Tourism Statistics-2018, MoCTCA (2019)

Hotels

According to Nepal Tourism Statistics- 2018 published in MoCTCA (2019), there are altogether 1254 registered hotels (Star and Tourist Standard Hotels) with a bed capacity of 40856 per day (MoCTCA, 2019)

\section{Airlines}

Nepal has 49 airports out of which 35 airports are in operations and 31 airports run in all seasons. Five airports are under construction and 14 are as non-functional. Twenty nine International Airlines carried 4382233 passengers in Nepal. There are 20 airlines for domestic movement (MoCTCA, 2019).

\section{Trekking Agencies}

Nepal is renowned for adventure tourism and the highest number of climbers came from China, USA, India, Germany and Japan respectively. There are 2649 registered trekking agencies in Nepal. Nepal Tourism Statistics-2018 report shows 147934 trekkers in Nepal which generates revenue of NRs. 46,92,26,347.7 and the royalty received by the peaks in 2018 was US\$ 1,062,816 (MoCTCA, 2019). Wengel (2020) writes that, for the second time in five years, the snowy slopes of Everest lie empty and silent after devastating earthquake-2015. COVID-19 has had enormous economic impacts in tourism industry across the globe. Likewise, Nepal economy is highly based on the tourism where adventure tourism is backbone of Nepal's economy, and the shutdown of expedition has affected livelihoods of around a million peopleincluding mountain guides and Sherpas, shops, restaurants, transportations, hotels, tea houses, B\&Bs and other tourism- related businesses. In 2019, Nepal's tourism 
industry based on mountain expedition generated NRs. 240 million /US\$ 1.6 billion (Wengel, 2020).

The tourism industry of Nepal also represents small operators, souvenir shops, ground handlers like tourist bus and car services, drivers and others dependent on tourism are severely affected. It has a spill over impact on almost every sector. People who are directly and indirectly dependent to the tourism industry are suffering. Small businesses are soon to collapse in Nepal as they have to survive through daily transaction. Thus, it is a very high time to rethink the alternate that could help economy recovery until tourism is back to its feet. Government of developing countries like Nepal will not be able to provide remedy to all the sectors since, the government itself is dependent to other nation in an arrangement of the basic essentials for a fight against virus. However, government must come forward with timely relief economic packages for the industry so that they could survive first. Survival of industry is must for the revival of industry. International recession will hit the country very hard as the country is dependent highly on the remittance. Hence, going back to village and economy uplift through agricultural revolution can provide oxygen to national GDP. According to assumption based report of $\mathrm{ADB}$, the decline in tourism receipts in the hypothetical worst case due to the COVID-19 pandemic is the same as the ones in the worst case. Therefore, the ADB staffs have presented their hypothetical data on different cases that will take place due to the outbreak of this virus.

Table 7: Decline in Tourism Revenues as an Impact of COVID-19 under Different Scenario

\begin{tabular}{|l|l|l|l|l|l|l|}
\hline \multirow{2}{*}{ Economy } & \multicolumn{2}{|c|}{ Best Case } & \multicolumn{2}{c|}{ Moderate Case } & \multicolumn{2}{c|}{ Worst Case } \\
\cline { 2 - 7 } & $\begin{array}{c}\text { as \% of } \\
\text { GDP }\end{array}$ & $\begin{array}{c}\text { in \$ } \\
\text { millions }\end{array}$ & $\begin{array}{c}\text { as \% of } \\
\text { GDP }\end{array}$ & $\begin{array}{c}\text { in \$ } \\
\text { millions }\end{array}$ & $\begin{array}{c}\text { as \% of } \\
\text { GDP }\end{array}$ & $\begin{array}{c}\text { in\$ } \\
\text { million }\end{array}$ \\
\hline Bangladesh & -0.001 & -3.1 & -0.002 & -4.7 & -0.003 & -9.4 \\
\hline Bhutan & -0.009 & -0.2 & -0.014 & -0.4 & -0.028 & -0.7 \\
\hline India & -0.003 & -84.2 & -0.005 & -126.3 & -0.009 & -252.7 \\
\hline Maldives & -1.839 & -98.0 & -2.758 & -147.0 & -5.517 & -293.9 \\
\hline Nepal & -0.033 & -9.7 & -0.050 & -14.5 & -0.100 & -29.1 \\
\hline China & -0.112 & $-15,241.6$ & -0.149 & $-20,215.0$ & -0.258 & $-35,135.3$ \\
\hline Sri-Lanka & -0.120 & -106.5 & -0.180 & -159.7 & -0.359 & -319.4 \\
\hline Thailand & -0.845 & $-4,265.8$ & $-1,224$ & $-6,180.2$ & $-2,361$ & $-11,923.5$ \\
\hline Myanmar & -0.149 & -106.3 & -0.224 & -159.4 & -0.448 & -318.8 \\
\hline
\end{tabular}

Source: ADB Briefs No. 128, 2020 
The crisis management strategy for recovery is concerned with the restoration and rehabilitation of industry. Hence, the stakeholders of tourism industry should focus on effective tourism planning, networking with international intermediaries, Assuring the safety and security at the destination, proper media management and so on. Costa (2020) develops a tourism planning model in a destination emphasizing on the assurance of safety and security of tourists in a destination. According to Korstanje et al. (2014), security plays pivotal role for expanding our existing understanding as how a risk is socially elaborated as a fear that affects travelers' motivation. Therefore, Safety and security at a destination assurance can help tourism growth. It is also a great idea to introduce free travel health insurance by the operators as a promotional tool to attract tourists. To cope up with this crisis, Nepal has adapted the policies and guidelines of World Health Organization (WHO). The preparedness of Nepal seems effective as the country has been able to stop the local transmission of virus. There is no report of escalation of local transmission of virus since April 4, 2020 which has been the only case in Nepal till April 11,2020. Similarly, the strategies and policies developed by UNWTO can be adapted that are feasible and relevant in reviving the tourism industry of Nepal. Enhanced international tourism networking amongst intermediaries; tourism destination planning \& restructuring for enhancing carrying capacity; assurance of health, safety \& security of tourists in a destination, provision of free medical insurances as a promotional campaign and so on are the few strategies that industry should address. Overall, the psychology of tourists will be impacted at least for few years until the virus is totally controlled and humans are rehabilitated. There will be major changes in tourist's buying behavior as a result- the choice of destination and attraction will change dramatically. Moreover, there will be a fear of mass tourism and group-travelling. Tourists will seek for sanitizer rather than welcome drinks during their check-ins in hotel; they expect staffs wearing mask and gloves; provision of regularly sanitizing the premises would determine the selection of accommodation.

\section{Conclusion}

This study attempted to explore the preliminary impacts of COVID-19 in tourism industry of Nepal. The pandemic will leave spill over impacts to all the sectors and can lead to severe short-term and long-term economic ramifications for global tourism industry. However, tourism will never decline forever nor will it remain flaccid for long as human's movement will always survive and provides spectrum for tourism revival. Travelers will be again mobilized as traveling is the dream of human who will be travelling for different motives. There have been many disastrous events and tourism crisis in the past. Negative events like- 9/11 attack on twin tower-USA; Mumbai- Taj attack; Earthquake in Nepal; Tsunami in Japan; SARS, MERS, Ebola, Zika Virus and many other pandemics have impacted global tourism brutally. However, with the 
strategies, ideas and joint effort of tourism stakeholders, the assurance of safety and security of the travelers have eradicated the tourism crisis and had rejuvenated.

There have been pandemic outbreaks prior COVID-19 as well (see table 2) which had impacted the travelers' mobility in the past too; however, the scars in a tourism industry as a residue of those events are eradicated with time. Hence, this is not a correct time to advocate the future of tourism since crisis management of COVID-19 outbreaks is still an ongoing process where tourism is not even a primary concern for the flaccid and anxious people in the present context. Every individual are panicked and wants to come out of this terror caused by COVID-19. Therefore, there is a need of further study on 'the impacts of COVID-19 in tourism industry of Nepal'. This study is just a preliminary research carried out to explore the effects on initial and continuously escalated status of COVID-19 in a real time.

Some scholars advocate that, there will be domestic mobility in the first stage which will provide a spectrum to reintroduce tourism. The mobility will gradually shift to regional countries which will boost the confidence and finally, travelers will travel to international arena for which it will however take a time. There is no doubt the tourism industry will enjoy the tourism nostalgia for few years. There will be many changes in travel policies that are yet to witness in future by "IATA, cruises, railways, other transportation, hotels and many associations which will definitely influences the travelers' motivation of traveling. There will also be new connotation in tourism academia by scholars and practitioners. Furthermore, stakeholders of tourism industry should be ready to accept the changes in tourists' behavior as a footprint of COVID-19.

\section{Acknowledgement}

First and foremost, my sincere thanks go to Prof. Dr. Ramesh Raj Kunwar, Tourism Educationist and Anthropologist, Former Dean of Faculty of Humanities and Social Sciences-Tribhhuvan University for his continuous guidance and support. Similarly, my gratitude also goes to my family members for their continuous cooperation.

\section{References}

ADB (2019). Macroeconomic update Nepal. Asian Development Bank, 7(1). [Retrieved From: https://www.adb.org/sites/default/files/institutional-document/495276/ nepal-macroeconomic-update-201904.pdf, Assessed on: April 1, 2020].

ADB Briefs (2020). The economic impact of the COVID-19 outbreak on developing Asia.

ADB Briefs No.128, Asian Development Bank. [Retrieved From: https://www.adb.org/ sites/default/files/publication/571536/adb-brief-128-economic-impact-covid19developing-asia.pdf, Assessed on: April 1, 2020]. 
Beirman, D. (2011). Bounce back: Tourism risk, crisis and recovery management guide, Sydeny. Pacific Asia Travel Association (PATA).

Coombs, W.T. (2007). Crisis management and communications. Institute for Public Relations [Retrieved From: https://instituteforpr.org/crisis-management-andcommunications, Assessed on: April 4, 2020].

Costa, C. (2020). Tourism planning: A perspective paper. Tourism review, 75(1), 198202 [Retrieved From: https://doi.org/10.1108/TR-09-2019-0394, Assessed on: April 10, 2020].

Guo, Y., Cao,Q., Hong, Z., Tan, Y., Chen, S., Jin, H., Tan, K., Wang, D., \& Yan, Y. (2020). The origin, transmission and clinical therapies on coronavirus disease 2019 (COVID-19) outbreak-an update on the status. Military Medical Research, 7(1). DOI: 10.1186/s40779-020-00240-0. [Retrieved From: https://www.researchgate. net/publication/339925460_The_origin_transmission_and_clinical_therapies_ on_coronavirus_disease_2019_COVID-19_outbreak_-_an_update_on_the_ status, Assessed on: April 6, 2020]

Haynes, S. (2020). As coronavirus spreads, so does xenophobia and anti-Asian racism. Time.com. [Retrieved From:https://time.com/5797836/coronavirusracism-stereotypes-attacks, Assessed on: April 4, 2020].

Hoek, L.V., Pyrc, K., Jebbink, M. et al. (2004). Identification of new human coronavirus. Nature Medicine, Nature Publishing Group, 10, 368-373. DOI: 10.1038/nm1024 [Retrieved From: https://www.nature.com/articles/nm1024, Assessed on: April 3, 2020].

Hu, Z., Yang, Z., Li, Q., Zhang, A., \&Huang, Y. (2020). Infodemiological study on COVID-19 epidemic and COVID-19 infodemic. DOI: 10.20944/ preprints202002.0380.v3 [Retrieved From: https://www.researchgate.net/ publication/339501808_Infodemiological_study_on_COVID-19_epidemic_ and_COVID-19_infodemic, Assessed on: April 7, 2020]

Hung, Y., Tseng, Y \& Petrick, J. (2007). Crisis management planning to restore tourism after disasters: A case study from Taiwan. Journal of Travel \& Tourism Marketing, 73(23), 2-16. DOI: 10.1300/JO73v23n02_16 [Retrieved From:http:// www.researchgate.net/publication/232951271, Assessed on April 2, 2020].

Hung, K.K., Mark, C.K., Yeung, M., Chan, E., Graham, C.A. (2018). The role of hotel industry in the response to emerging epidemics: A case study of SARS in 2003 and H1N1 Swine flu in 2009 in Hong Kong", Globalization and Health, 14(1), 1-7. Doi: 10.1186/s12992-018-0438-6. [Retrieved From: https:/globalizationandhealth. biomedcentral.com/track/pdf/10.1186/s12992-018-0438-6, Assessed on: April 5, 2020]. 
Institute of Public Relations (2007). Crisis management and communications. The Science Beneath the Art of Public Relations. [Retrieved From: https://instituteforpr. org/crisis-management-and-communications/, Assessed on: April 11, 2020].

Jamal, T. \& Budke, C. (2020). Tourism in a world with pandemics: Local-global responsibility and action. Journal of Tourism Futures. DOI 10.1108/JFT-02-20200014 [Retrieved From: https://www.emerald.com/insight/content/doi/10.1108/ JTF-02-2020-0014/full/pdf, Assessed on: April 1, 2020].

Korstanje, M.E., Skoll, G. \& Timmermann, F. (2014). Terrorism, tourism and worker unions: The disciplinary boundaries of fear. International Journal of Religious Tourism and Pilgrimage, 2(1), 1-12. [Retrieved From: https://arrow.tudublin.ie/ cgi/viewcontent.cgi? article=1058\&context=ijrtp, Assessed on: April 6, 2020]

Kunwar, R.R. (2010). Tourists and Tourism. Science and Industry Interface. Kathmandu: Ganga Sen Kunwar.

Kunwar, R. R (2012). Safety and security in tourism: A study of crisis and disaster management. Journal of Tourism and Hospitality Education, 2, 58-83.

Kunwar, R.R. (2016). Tourism crisis and disaster management. The Gaze: Journal of Tourism and Hospitality, 7(1), 1-36.

Lau, S.K., \& Chan, J.F. (2015).Coronaviruses: Emerging and re-emerging pathogens in humans and animals. Virology Journal, 12:209. DOI 10.1186/s12985-0150432-z [Retrieved From: https://virologyj.biomedcentral.com/articles/10.1186/ s12985-015-0432-z, Assessed on: April 7, 2020].

Luhrman, D. (2003). Crisis guidelines for the tourism industry. Asia Pacific Ministerial Summit on Crisis Management, Manila.

Mair, J., Ritchie, B.W., \& Walter, G. (2016). Towards a research agenda for post-disaster and post-crisis recovery strategies for tourism destinations: A narrative review. Current Issues in Tourism, 19(1), 1-26. doi: 10.1080/13683500.2014.932758. [Retrieved From: https://www.researchgate.net/publication/271752570_ Towards_a_research_agenda_for_post-disaster_and_post-crisis_recovery_ strategies_for_tourist_destinations_a_narrative_review, Assessed on: April 5, 2020].

Maxouris, C. (2020). US enforces coronavirus travel restrictions: China says it's an overreaction. CNN, CNN Travel. [Retrieved From: https:/edition.cnn.com/ travel/article/coronavirus-us-travel-restrictions-monday/index.html Assessed on April 3, 2020].

MoCTCA (2014). Tourism Employment Survey. Ministry of Culture, Tourism \& Civil Aviation, Planning and Evaluation Division, Government of Nepal. 
[Retrieved From: https://www.taan.org.np/assets/upload/downloads/ download_Tourism_Employment_Study_Draft_Report_integrated.pdf, Assessed on: April 5, 2020].

MoHP (2020). Department of Health Services. [Retrieved From: https://dohs.gov. np/about-us/department-of-health-services/?lang=ne, Assessed on: April 11, 2020].

Morens, D.M., Folkers, G.K., \& Fauci, A.S. (2009). What is pandemic? National Institute of Allergy and Infectious Diseases, National Institute of Health, Bethesda, Maryland. [Retrieved from: https://academic.oup.com/jid/article/200/7/1018/903237, Assessed on: April 4, 2020].

Nepal Tourism Statistics (2019). Ministry of Culture, Tourism \& Civil Aviation, Government of Nepal. [Retrieved From: https://tourism.gov.np/files/statistics/19. pdf, Assessed on: April 2, 2020].

Neupane, A. (2020). Nepal in second stage of COVID-19 transmission. My Republica. [Retrieved From: https://myrepublica.nagariknetwork.com/news/nepal-insecond-stage-of-covid-19-transmission/, Assessed on: April 11, 2020].

Pike, B.L., Saylors, K.E., Fair, J.N. et al. (2010). The origin and prevention of pandemics. Clinical Infectious Disease, 50(12), 1636-1640. Doi: 10.1086/652860 [Retrieved From: https://www.ncbi.nlm.nih.gov/pmc/articles/PMC2874076/, Assessed on: April 5, 2020].

Prasain, S. (2019). Nepal tourism generated Rs.240b and supported $1 \mathrm{~m}$ jobs last year: report. The Kathmandu Post. [Retrieved from: https://kathmandupost.com/ money/2019/05/26/nepal-tourism-generated-rs240b-and-supported-1m-jobslast-year-report Assessed on: April 5, 2020].

Rocca, R.A. (2015). Tourism mobility. Best practices and conditions to improve urban livability. TeMA- Journal of Land Use, Mobility and Environment, 8(3), 1-330. DOI: 10.6092/1970-9870/2814 [Retrieved From: https://www.researchgate. net/publication/293175478_Tourism_and_Mobility_Best_Practices_and_ Conditions_to_Improve_Urban_Livability, Assessed on: April 6, 2020]

Rubin, H. (2011). Future global shocks: Pandemics. Multi-Disciplinary Issues: International Future Program, OECD. [Retrieved from: https://www.oecd.org/fr/ gouvernance/risques/Pandemics.pdf, Assessed on: April 2, 2020]

Shrestha, P.M. (2020). Nepali economy starts to feel the pinch as coronavirus spreads. The Kathmandu Post. [Retrieved From: https://kathmandupost.com/ national/2020/03/04/nepali-economy-starts-to-feel-the-pinch-as-coronavirusspreads, Assessed on: April 5, 2020] 
Sönmez, S.F., Backman, S.J., \& Allen, L.R. (1994). Managing Tourism Crises: A Guide Book. Department of Parks, Recreation, and Tourism Management, South Carolina: Clemson University.

Subba, S. (2020). Nepal's economy, already weak, takes direct hit. Nepali Times. [Retrieved From: https://www.nepalitimes.com/here-now/nepals-economyalready-weak-takes-direct-hit/, Assessed on: April 2, 2020]

The Economic Times (2020). Coronavirus: The four stages of global pandemic. ET Online. [Retrieved From: https://economictimes.indiatimes.com/news/politicsand-nation/coronavirus-the-four-stages-of-a-global-pandemic/pandemic/ slideshow/74884293.cms, Assessed on: April 11, 2020].

The World Bank (2020). The government of Nepal and the World Bank Sign \$29 million financing agreement for Nepal's COVID-19 (Coronavirus) responses. Press release. The World Bank. [Retrieved From: https://www.worldbank.org/en/ news/press-release/2020/04/03/world-bank-fast-tracks-29-million-for-nepalcovid-19-coronavirus-response, Assessed on: April 11, 2020].

Tse, T. (2006). Crisis management in tourism. In Buhalis, D. \& Costa, C. (Eds.) Tourism Management Dynamics: Trends, Management, Tools, Oxford: Elsevier, Pp. 28-38.

Ulak, N. (2016). Nepal's earthquake-2015: Its impact on various sectors. The Gaze: Journal of Tourism and Hospitality, 79(1), 58-86. htpps://doi.org/10.3126/gaze. v7i0.15120

UNWTO (2020). Coronavirus: The world economy at risk. OECD Interim Economic Assessment. [Retrieved from: https://www.unwto.org/unwto-statement-on-thenovel-coronavirus-outbreak, Assessed on: March 30, 2020]

Weiss, S.R. \& Martin, S.N. (2005). Coronavirus pathogenesis and emerging pathogen severe acute respiratory syndrome coronavirus. Microbiology and Molecular Biology Reviews, American Society of Microbiology, 69(4), 635-664. DOI:10.1128/MMBR.69.4.635-664.2005 [Retrieved From: https://mmbr.asm. org/content/69/4/635, Assessed on: March 31, 2020].

Wengel, Y. (2020). Everest is closed- enforced hiatus will help its environment recover but hit a million livelihoods. The conversation. [Retrieved From: https://theconversation.com/everest-is-closed-enforced-hiatus-will-help-itsenvironment-recover-but-hit-a-million-livelihoods-134339, Assessed on: April $9,2020]$.

WHO (2020). Coronavirus disease 2019 (Covid-19). Situation Report. World Health Organization. [Retrieved From: https:/www.who.int/emergencies/diseases/ novel-coronavirus-2019/situation-reports, Assessed on: March 15, 2020]. 
WTTC (2019). Travel and tourism economic impact 2019. World Travel and Tourism Council. [Retrieved From: https://www.wttc.org/-/media/files/reports/economicimpact-research/regions-2019/world2019.pdf Assessed on: April 4, 2020].

Zhang, J.G. (2020). Corona beer still struggling with confused consumers amid coronavirus fears. Eater.com. [Retrieved From: https://www.eater. com/2020/2/28/21157594/coronavirus-covid-19-corona-beer-confusioncontinues, Assessed on: April 1, 2020].

\section{Website URLs}

https://webunwto.s3.eu-west-1.amazonaws.com/s3fs-public/2020-02/31012020\%20 Coronavirus\%20EN.pdf

https://www.mckinsey.com/ /media/McKinsey/Business\%20Functions/Risk/ Our\%20Insights/COVID\%2019\%20Implications\%20for\%20business/ COVID\%2019\%20March\%209/COVID-19-Briefing-note-March-9-2020-v5. ashx

https://www.mckinsey.com/ /media/McKinsey/Business\%20Functions/Risk/ Our\%20Insights/COVID\%2019\%20Implications\%20for\%20business/ COVID\%2019\%20March\%209/COVID-19-Facts-and-Insights-March-9-2020v2.ashx

https://www.cdc.gov/coronavirus/2019-ncov/downloads/2019-ncov-factsheet.pdf

https://health.usnews.com/conditions/articles/whats-the-difference-between-anepidemic-and-pandemic

https://www.who.int/health-topics/coronavirus

https://www.mckinsey.com/business-functions/risk/our-insights/covid-19implications-for-business

https://www.weforum.org/agenda/2020/02/the-coronavirus-will-hit-the-tourismand-travel-sector-hard/

https://www.who.int/publications-detail/global-survellience-for-human-infectionwith-novel-coronavirus-(2019-ncov).

www.iata.org/en/programs/safety/health/diseases/\#tab-2

https://www.researchgate.net/publication/8666166,

http://www.nature.com/naturemedicine, 